\title{
Investigation of the efficiency of gas condensate reservoirs waterflooding at different stages of development
}

\author{
Oleksandr Burachok ${ }^{1}$, Oleksandr Kondrat $^{1 *}$, and Serhii Matkivskyi ${ }^{2}$ \\ ${ }^{1}$ Ivano-Frankivsk National Technical University of Oil and Gas, Department of Petroleum Production, \\ 15 Karpatska St, 76019, Ivano-Frankivsk, Ukraine \\ ${ }^{2}$ Joint-Stock Company "Ukrgazvydobuvannya", Branch "Ukrainian Research Institute of Natural \\ Gases", 20 Gymnasium Embankment, 61010, Kharkiv, Ukraine
}

\begin{abstract}
The study of flooding gas condensate reservoirs at different stages of depletion $(25,50,75 \%$ of the dew point pressure and at the maximum condensation pressure) with different potential hydrocarbon content of 100,300 and $500 \mathrm{~g} / \mathrm{m}^{3}$ and different voidage replacement by using injection $(50,100$ and $150 \%)$. The results showed a positive effect of water injection on the increase of the condensate recovery factor, but a decrease in gas production compared to the basic options of development at depletion drive. Thus, for formation systems with medium and high potential yield of liquid hydrocarbons $\mathrm{C}_{5+}$, the largest incremental production is obtained in the case when water injection begins with minimum depletion of formation energy. While for a formation system with a low potential yield $\left(100 \mathrm{~g} / \mathrm{m}^{3}\right)$ the maximum technological effect is obtained under the condition of maximum depletion. In the case of medium and high $\mathrm{C}_{5}+$ yield in the formation gas, with a slight decrease in the formation pressure by 25 or $50 \%$ of the dew point pressure, the maximum increase in the condensate recovery factor is achieved at high injection rates with 100 or $150 \%$ voidage replacement. The obtained results can be used for rapid screening of potential methods of impact on the gas condensate reservoir, and the final decision concerning the technological parameters of production and injection wells operation will be made due to the results of optimization of multivariate hydrodynamic calculations using geological and technological models.
\end{abstract}

\section{Introduction}

The design of hydrocarbon reservoirs development is based on a deep understanding of the processes occurring in the formation, namely multi-phase filtration and phase transformations of multicomponent hydrocarbon systems.

With regard to gas condensate fields, it is necessary to pay attention to certain features associated with the heavy hydrocarbons condensation when the formation pressure is reduced below the dew point pressure. The vast majority of gas condensate fields in

*Corresponding author: kondrat@nung.edu.ua 
Ukraine, with the exception of the K-30 Novo-Troitsky, T-1 Timofiyivsky, S-5 Kotelevsky and T-1 Kulychykhynsky horizons, are developed at depletion drive. Therefore, in gas condensate deposits developed without maintaining the reservoir pressure, a part of hydrocarbon condensate drops out of the gas. Condensed hydrocarbons precipitated in a porous medium do not move and are practically not extracted. Condensate production is observed only from the small bottomhole zone around the wells. At the same time, the accumulation of condensate in the bottomhole zone and at the bottom of the wells can lead to a decrease in their productivity and subsequent premature shutdown. The coefficient of final condensate recovery in the development of gas condensate fields at the depletion drive is only $13-40 \%[1,2]$.

To increase the gas condensate recovery factor and improve the technical and economic indicators of hydrocarbon production, gas condensate fields, as well as oil fields, should be developed with the maintenance of formation pressure. Maintenance of the reservoir pressure in gas condensate fields can be carried out by revers injection of separated (dry) gas, use of dry gas of oil fields, non-hydrocarbon gases (nitrogen, carbon dioxide, air, flue and exhaust gases), artificial hydrocarbons which is obtained by hydrocarbon conversion by water steam, mixtures of hydrocarbon and non-hydrocarbon gases, of water and gas-water mixtures injection. [1, 3-11].

In field practice, a complete or partial cycling process is mainly used with injection into the formation of all or part of the separated dry gas.

Given the acute shortage of hydrocarbon crude in Ukraine, the involvement into the development of residual reserves of condensate that fell out from the gas in the reservoir is of national importance. A number of methods for the production of condensed hydrocarbons are proposed, which are reviewed in $[2,3,12,13]$.

Possible directions of condensate recovery dropped out from the gas in the formation are its transfer into the gas phase with subsequent extraction together with the gas, displacement from the porous medium by different working agents and their combination $[2,3,12,13-15]$. The results of laboratory experiments on condensate displacement by water from models of porous media conducted in IFNTUNG were used in the design of further development of the Gadyach gas condensate field (horizon B-16) using intracontour (focal) flooding $[7,16]$ and in the design of secondary condensate recovery from partial depleted gas condensate deposit of the horizon B-19b of the Anastasiyivske field $[11,17]$.

In this work, we study the efficiency of flooding a typical gas condensate deposit at different stages of depletion and with different compositions of formation fluids, expressed in different potential yields of liquid hydrocarbons, to determine the optimal compensation of withdrawal by injection depending on the potential yield.

\section{Statement of a numerical experiment}

To study the efficiency of enhanced hydrocarbon recovery from the gas condensatereservoir, a synthetic numerical model of the reservoir was used, as close as possible to the conditions of deep deposits of the Dnieper-Donets depression (DDD). The reservoir measuring $6.7 \times 2.0 \mathrm{~km}$, with a thickness of about $100 \mathrm{~m}$ is located in the range of depths between -3000 and $-3100 \mathrm{~m}$, represented by a homogeneous grid of 188 thousand active cells. Four lithological rock types (clay and three sandstones) are stochastically distributed over the volume of the reservoir using the method of sequential indicator simulation. For each rock type, the porosity is assigned using the Monte Carlo method based on the normal porosity versus rocks for each class. The average porosity values for the rock types are 9,11 and 16\%, respectively. Most of the reservoirs (56\%) are composed of coarse-grained sandstone with permeability above $10 \mathrm{mD}$. It is assumed that each rock 
type is characterized by intermediate wettability with corresponding relative phase permeability and capillary pressures.

The effect of different methods was investigated using compositional simulations for three different synthetically generated reservoir fluid systems with low $\left(100 \mathrm{~g} / \mathrm{m}^{3}\right)$, medium $\left(300 \mathrm{~g} / \mathrm{m}^{3}\right)$ and high $\left(500 \mathrm{~g} / \mathrm{m}^{3}\right)$ initial potential yield of $\mathrm{C}_{5+}$ hydrocarbons (Fig. 1) based on the developed methods [18-20].

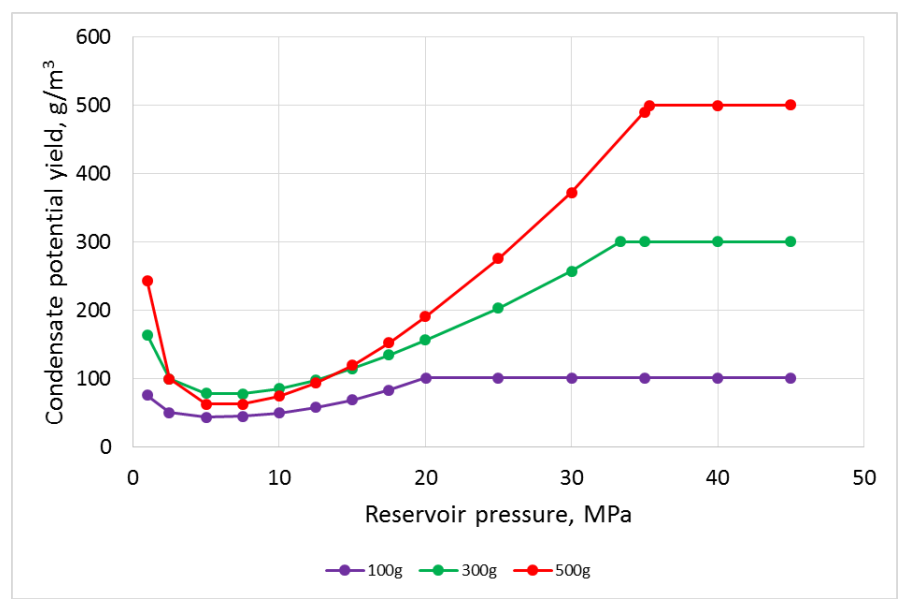

Fig. 1. $\mathrm{C}_{5}$ hydrocarbons potential yield in reservoir fluid systems.

The reservoir is developed by 14 unevenly placed vertical production wells in the crest section with distances between the wells from 550 to $750 \mathrm{~m}$ (Fig. 2). All the wells were perforated against the intervals with the best (coarse-grained) rock type with zero skin factor. A generalized pseudo-pressure method is used as the inflow equation to the production wells. It is the best suited for gas condensate wells of all IPRs implemented in the hydrodynamic simulator ECLIPSE by Schlumberger, because it corrects the mobility of both gas and liquid hydrocarbon phases which allows considering the effect of dropping out condensate in bottom hole zone due to a specially introduced "blocking factor" [21].

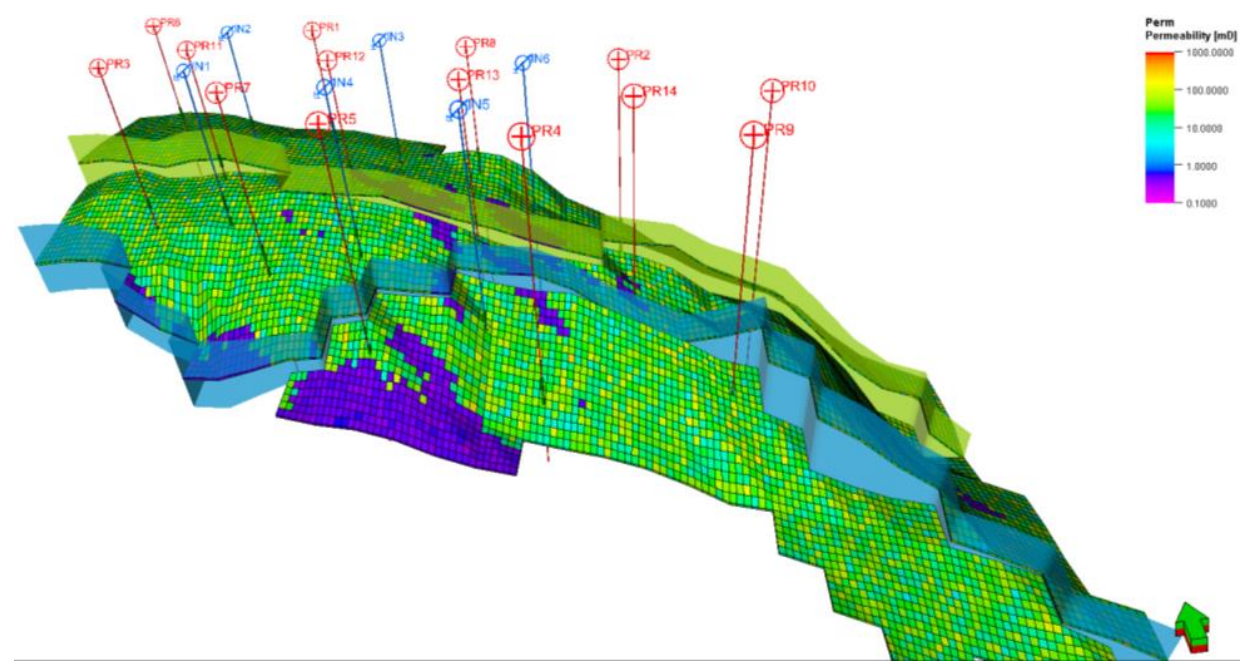

Fig. 2. Example of permeability distribution for one of the layers in the model shown together with two present faults, production (red) and injection (blue) wells. 
All production wells operate into one Gas Treatment Unit (GTU) with a total group limit of 7 million $\mathrm{m}^{3} / \mathrm{d}$, and the flow rates of individual wells are calculated automatically based on their ranking by the values of maximum free flow rate, but not more than 0.5 million $\mathrm{m}^{3} / \mathrm{d}$. If it is not possible to satisfy a given group rate, the wells are switched to downhole pressure control with a limit of $4 \mathrm{MPa}$.

First, the calculation of indicators for the base case at depletion drive for 30 years (Table 1 and Fig. 3) was performed. Since the conditions of the well control were the same in all cases, the period of continuous production decreases with increasing potential yield (1.5 years shorter) with the gradual transition of wells to downhole pressure control, which in turn also affects the cumulative production. However, regardless of the potential yield, at abandonment pressure of $4 \mathrm{MPa}$, in all the cases the same gas recovery coefficients of about $89 \%$ were obtained. At the same time, with the increase of the potential yield, the losses of the dropped out condensate increase significantly, which leads to the reduction of the recovery factor from $70 \%$ for $100 \mathrm{~g} / \mathrm{m}^{3}$ to $40 \%$ in the case of high content at the level of $500 \mathrm{~g} / \mathrm{m}^{3}$. One of the most important factors here is the growth of the dew point pressure, and its approximation to the initial formation pressure, which leads to the rapid formation of the liquid hydrocarbon phase, first in the $\mathrm{BH}$ zone and later in the intra-well area.

Table 1. Development parameters due to the basic variant at depletion drive.

\begin{tabular}{|c|c|c|c|c|c|}
\hline \multirow{2}{*}{ Model } & \multirow{2}{*}{$\begin{array}{c}\text { Final reservoir } \\
\text { pressure, MPa }\end{array}$} & \multicolumn{2}{|c|}{ Cumulative production } & \multicolumn{2}{|c|}{ Recovery factor, \% } \\
\cline { 3 - 6 } & gas, billion $\mathrm{m}^{3}$ & $\begin{array}{c}\text { condensate, } \\
\text { billion } \mathrm{m}^{3}\end{array}$ & gas & condensate \\
\hline $100 \mathrm{~g} / \mathrm{m}^{3}$ & 4.016 & 39.388 & 4.662 & 89.16 & 69.61 \\
\hline $300 \mathrm{~g} / \mathrm{m}^{3}$ & 4.018 & 38.114 & 6.924 & 89.09 & 47.11 \\
\hline $500 \mathrm{~g} / \mathrm{m}^{3}$ & 4.018 & 36.108 & 9.561 & 88.86 & 40.34 \\
\hline
\end{tabular}

According to the base cases, the time corresponding to the pressure drop by $25,50,75 \%$ of the dew point pressure and the maximum condensation pressure is determined. Injection was carried out into 6 additionally drilled injection wells. When injecting water, the maximum downhole pressure is limited to $70 \mathrm{MPa}$ (conventional hydraulic fracturing pressure), production wells automatically shut down when the water-gas ratio of $0.005 \mathrm{~m}^{3} / \mathrm{m}^{3}(5750$ $\mathrm{g} / \mathrm{m}^{3}$ ), which characterizes complete flooding and the impossibility of further wells operation.

(a)

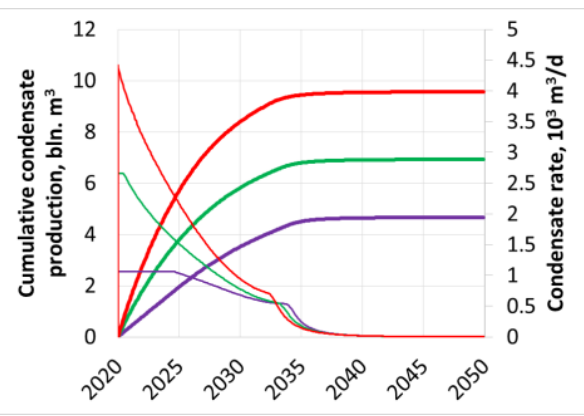

(b)

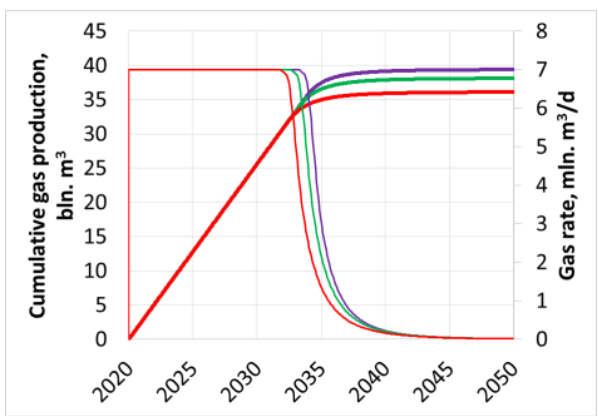

Fig. 3. Gas (a) and condensate (b) recovery profiles for the base cases (magenta $-100 \mathrm{~g} / \mathrm{m}^{3}$, green $-300 \mathrm{~g} / \mathrm{m}^{3}$, red $\left.-500 \mathrm{~g} / \mathrm{m}^{3}\right)$.

The analysis of the efficiency of the methods was performed according to two criteria:

- technological - additional production of condensate;

- economic - net present value (NPV) by simplified calculation based on the data given in Table 2. 
Table 2. Initial data for economic calculations of net present value.

\begin{tabular}{|l|c|c|}
\hline \multicolumn{2}{|c|}{ Parameter } & Value \\
\hline \multirow{2}{*}{ The cost of marketable products, USD $/ \mathrm{m}^{3}$} & Condensate & 700.00 \\
\cline { 2 - 3 } & Gas & 0.65 \\
\hline \multirow{3}{*}{ Operating costs of production, USD $/ \mathrm{m}^{3}$} & Water & 5.00 \\
\cline { 2 - 3 } & Condensate & 350.00 \\
\cline { 2 - 3 } & Gas & 0.20 \\
\hline Injection costs, USD $/ \mathrm{m}^{3}$ & Water & 1.00 \\
\hline Annual discount rate, $\%$ & & 10.0 \\
\hline
\end{tabular}

\section{Calculation results analysis}

The results of the calculations for each stage of the depletion are summarized in Tables 3-6 and Figures 4-7. Blue colours correspond to the potential content of $100 \mathrm{~g} / \mathrm{m}^{3}$, green $300 \mathrm{~g} / \mathrm{m}^{3}$, pink - $500 \mathrm{~g} / \mathrm{m}^{3}$, and shades - the percentage of withdrawal compensation by injection, light $-50 \%$, intermediate $-100 \%$, dark $-150 \%$. Incremental production is calculated relative to the base cases of development under depletion drive.

Table 3. Results for the beginning of flooding at a pressure of $25 \%$ of the dew point pressure.

\begin{tabular}{|c|c|c|c|c|c|c|c|}
\hline \multirow{3}{*}{ Model } & $\begin{array}{c}\text { Voidage } \\
\text { replace- } \\
\text { ment } \\
\text { ratio, } \%\end{array}$ & $\begin{array}{c}\text { Cumula- } \\
\text { tive gas } \\
\text { produc- } \\
\text { tion, bln. } \\
\mathrm{m}^{3}\end{array}$ & $\begin{array}{c}\text { Gas- } \\
\text { recov- } \\
\text { ery } \\
\text { factor, } \\
\%\end{array}$ & $\begin{array}{c}\text { Incre- } \\
\text { mental } \\
\text { gas pro- } \\
\text { duction, } \\
\text { bln. } \mathrm{m}^{3}\end{array}$ & $\begin{array}{c}\text { Cumula- } \\
\text { tive con- } \\
\text { densate } \\
\text { produc- } \\
\text { tion, bln. } \\
\mathrm{m}^{3}\end{array}$ & $\begin{array}{c}\text { Conden- } \\
\text { sate } \\
\text { recovery } \\
\text { factor, } \\
\%\end{array}$ & $\begin{array}{c}\text { Incremental } \\
\text { condensate } \\
\text { production, } \\
\text { bln. } \mathrm{m}^{3}\end{array}$ \\
\hline \multirow{3}{*}{$100 \mathrm{~g} / \mathrm{m}^{3}$} & 50 & & \multicolumn{7}{|c|}{ No results } \\
\cline { 2 - 9 } & 100 & 37.075 & 83.93 & -2.313 & 4.743 & 70.50 & 0.081 \\
\cline { 2 - 9 } $300 \mathrm{~g} / \mathrm{m}^{3}$ & 150 & 36.341 & 82.27 & -3.047 & 4.689 & 69.69 & 0.027 \\
\cline { 2 - 9 } & 50 & 37.987 & 89.18 & -0.127 & 7.679 & 47.56 & 0.755 \\
\hline \multirow{3}{*}{$500 \mathrm{~g} / \mathrm{m}^{3}$} & 100 & 32.064 & 75.27 & -6.050 & 7.828 & 48.48 & 0.904 \\
\cline { 2 - 9 } & 150 & 30.768 & 72.23 & -7.346 & 7.759 & 48.05 & 0.835 \\
\cline { 2 - 9 } & 100 & 35.548 & 83.45 & -0.560 & 10.837 & 42.11 & 1.276 \\
\hline
\end{tabular}

Table 4. Results for the beginning of flooding at a pressure of $50 \%$ of the dew point pressure.

\begin{tabular}{|c|c|c|c|c|c|c|c|}
\hline \multirow{3}{*}{ Model } & $\begin{array}{c}\text { Voidage } \\
\text { replace- } \\
\text { ment } \\
\text { ratio, } \%\end{array}$ & $\begin{array}{c}\text { Cumula- } \\
\text { tive gas } \\
\text { produc- } \\
\text { tion, bln. } \\
\mathrm{m}^{3}\end{array}$ & $\begin{array}{c}\text { Gas- } \\
\text { recov- } \\
\text { ery } \\
\text { factor, } \\
\%\end{array}$ & $\begin{array}{c}\text { Incre- } \\
\text { mental } \\
\text { gas pro- } \\
\text { duction, } \\
\text { bln. }{ }^{3}\end{array}$ & $\begin{array}{c}\text { Cumula- } \\
\text { tive con- } \\
\text { densate } \\
\text { produc- } \\
\text { tion, bln. } \\
\mathrm{m}^{3}\end{array}$ & $\begin{array}{c}\text { Conden- } \\
\text { sate } \\
\text { recovery } \\
\text { factor, } \\
\%\end{array}$ & $\begin{array}{c}\text { Incremental } \\
\text { condensate } \\
\text { production, } \\
\text { bln. } \mathrm{m}^{3}\end{array}$ \\
\hline \multirow{3}{*}{$100 \mathrm{~g} / \mathrm{m}^{3}$} & 50 & 40.535 & 91.77 & 1.147 & 4.796 & 71.29 & 0.134 \\
\cline { 2 - 9 } & 100 & 38.433 & 87.01 & -0.955 & 4.690 & 69.70 & 0.028 \\
\hline \multirow{3}{*}{$300 \mathrm{~g} / \mathrm{m}^{3}$} & 150 & 35.222 & 79.74 & -4.166 & 4.672 & 69.44 & 0.010 \\
\cline { 2 - 9 } & 100 & 38.632 & 90.69 & 0.518 & 7.275 & 45.06 & 0.351 \\
\cline { 2 - 9 } $500 \mathrm{~g} / \mathrm{m}^{3}$ & 150 & 32.767 & 81.62 & -3.347 & 7.217 & 44.70 & 0.293 \\
\cline { 2 - 8 } & 100 & 38.416 & 90.18 & -6.063 & 7.159 & 44.34 & 0.235 \\
\cline { 2 - 8 } & 150 & 33.917 & 79.62 & -2.191 & 10.065 & 39.11 & 0.534 \\
\hline
\end{tabular}


Table 5. Results for the beginning of flooding at a pressure of $75 \%$ of the dew point pressure.

\begin{tabular}{|c|c|c|c|c|c|c|c|}
\hline \multirow{3}{*}{ Model } & $\begin{array}{c}\text { Voidage } \\
\text { replace- } \\
\text { ment } \\
\text { ratio, } \%\end{array}$ & $\begin{array}{c}\text { Cumula- } \\
\text { tive gas } \\
\text { produc- } \\
\text { tion, bln. } \\
\mathrm{m}^{3}\end{array}$ & $\begin{array}{c}\text { Gas- } \\
\text { recov- } \\
\text { ery } \\
\text { factor, } \\
\%\end{array}$ & $\begin{array}{c}\text { Incre- } \\
\text { mental } \\
\text { gas pro- } \\
\text { duction, } \\
\text { bln. }{ }^{3}\end{array}$ & $\begin{array}{c}\text { Cumula- } \\
\text { tive con- } \\
\text { densate } \\
\text { produc- } \\
\text { tion, bln. } \\
\mathrm{m}^{3}\end{array}$ & $\begin{array}{c}\text { Conden- } \\
\text { sate } \\
\text { recovery } \\
\text { factor, } \\
\%\end{array}$ & $\begin{array}{c}\text { Incremental } \\
\text { condensate } \\
\text { production, } \\
\text { bln. } \mathrm{m}^{3}\end{array}$ \\
\hline \multirow{3}{*}{$100 \mathrm{~g} / \mathrm{m}^{3}$} & 50 & 40.606 & 91.93 & 1.218 & 4.757 & 70.70 & 0.095 \\
\cline { 2 - 9 } & 100 & 38.687 & 87.58 & -0.701 & 4.713 & 70.05 & 0.051 \\
\cline { 2 - 9 } $300 \mathrm{~g} / \mathrm{m}^{3}$ & 150 & 36.366 & 82.33 & -3.022 & 4.710 & 70.01 & 0.048 \\
\cline { 2 - 9 } & 100 & 40.006 & 93.91 & 1.892 & 7.026 & 43.52 & 0.102 \\
\hline \multirow{3}{*}{$500 \mathrm{~g} / \mathrm{m}^{3}$} & 150 & 35.539 & 88.12 & -0.575 & 6.971 & 43.18 & 0.047 \\
\cline { 2 - 8 } & 100 & 39.967 & 92.56 & -2.943 & 6.960 & 43.11 & 0.036 \\
\cline { 2 - 8 } & 150 & 35.411 & 87.82 & 3.859 & 9.672 & 37.58 & 0.111 \\
\hline
\end{tabular}

Table 6. Results to start flooding at maximum condensation pressure.

\begin{tabular}{|c|c|c|c|c|c|c|c|}
\hline \multirow{3}{*}{ Model } & $\begin{array}{c}\text { Voidage } \\
\text { replace- } \\
\text { ment } \\
\text { ratio, \% }\end{array}$ & $\begin{array}{c}\text { Cumula- } \\
\text { tive gas } \\
\text { produc- } \\
\text { tion, bln. } \\
\mathrm{m}^{3}\end{array}$ & $\begin{array}{c}\text { Gas- } \\
\text { recov- } \\
\text { ery } \\
\text { factor, } \\
\%\end{array}$ & $\begin{array}{c}\text { Incre- } \\
\text { mental } \\
\text { gas pro- } \\
\text { duction, } \\
\text { bln. } \mathrm{m}^{3}\end{array}$ & $\begin{array}{c}\text { Cumula- } \\
\text { tive con- } \\
\text { densate } \\
\text { produc- } \\
\text { tion, bln. } \\
\mathrm{m}^{3}\end{array}$ & $\begin{array}{c}\text { Conden- } \\
\text { sate } \\
\text { recovery } \\
\text { factor, } \\
\%\end{array}$ & $\begin{array}{c}\text { Incremental } \\
\text { condensate } \\
\text { production, } \\
\text { bln. } \mathrm{m}^{3}\end{array}$ \\
\hline \multirow{3}{*}{$100 \mathrm{~g} / \mathrm{m}^{3}$} & 50 & 41.165 & 93.19 & 1.777 & 4.803 & 71.38 & 0.141 \\
\cline { 2 - 8 } & 100 & 39.752 & 89.99 & 0.364 & 4.780 & 71.05 & 0.118 \\
\hline \multirow{3}{*}{$300 \mathrm{~g} / \mathrm{m}^{3}$} & 150 & 37.630 & 85.19 & -1.758 & 4.776 & 70.98 & 0.114 \\
\cline { 2 - 9 } & 50 & 40.935 & 96.10 & 2.821 & 7.057 & 43.71 & 0.133 \\
\hline \multirow{3}{*}{$500 \mathrm{~g} / \mathrm{m}^{3}$} & 100 & 39.481 & 92.68 & 1.367 & 7.029 & 43.54 & 0.105 \\
\cline { 2 - 8 } & 150 & 37.315 & 87.60 & -0.799 & 7.025 & 43.51 & 0.101 \\
\cline { 2 - 8 } & 100 & 40.885 & 95.98 & 4.777 & 9.712 & 37.73 & 0.151 \\
\hline
\end{tabular}

As can be seen from the Tables 3-6, only in the case of flooding at the maximum condensation pressure, there is incremental gas production, with the same insignificant condensate production at the level of 0.1 million $\mathrm{m}^{3}$ for all potential yields. If the flooding starts early enough, when the formation pressure is by $25 \%$ lower than the dew point pressure, on the account of rapid water breakthrough and production wells shutdown due to reaching the critical water-gas ratio, gas production losses are compared to the base cases range from 2 to 8 billion $\mathrm{m}^{3}$ while providing high additional condensate production of $0.7-0.9$ million $\mathrm{m}^{3}$ for the reservoir fluid system of $300 \mathrm{~g} / \mathrm{m}^{3}$ and $1.2-1.6$ million $\mathrm{m}^{3}$ for $500 \mathrm{~g} / \mathrm{m}^{3}$, which indicates the efficient condensate recovery by water.

At high voidage replacement ratios of $100 \%$ and $150 \%$ there is a rapid breakthrough of water to most of the production wells leading to complete flooding for 4 years of injection, at the same time the value of voidage replacement does not significantly affect the condensate recovery the curves of cumulative production for similar potential yields overlap each other. The higher the potential yield, the faster the water breakthrough occurs. The economic efficiency of the development is completely determined by the duration of the period of continuous production and directly depends on the amount of condensate production. At the end of the development, all options with water flooding reach zero net cost, confirming the economic efficiency of the flooding. 
(a)

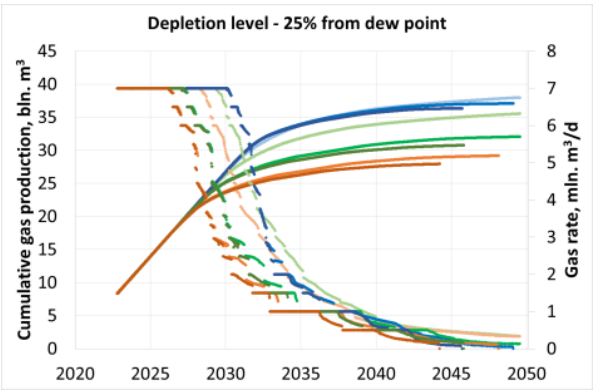

(c)

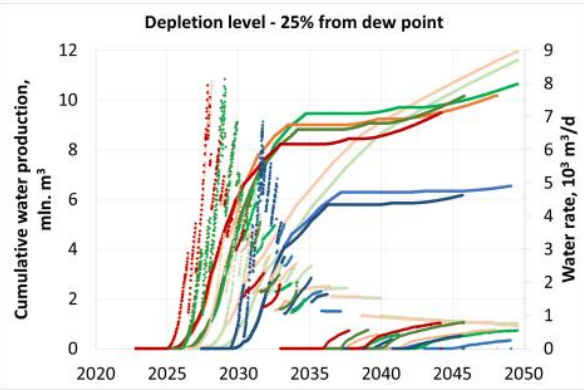

(b)

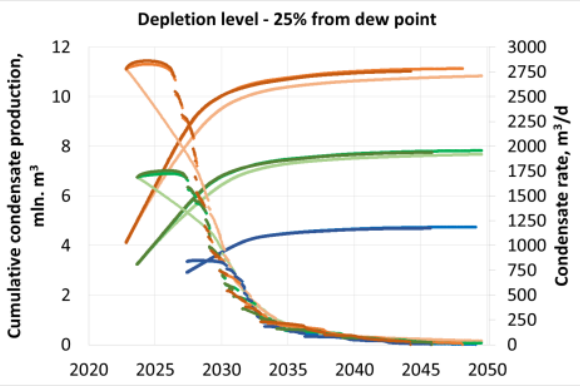

(d)

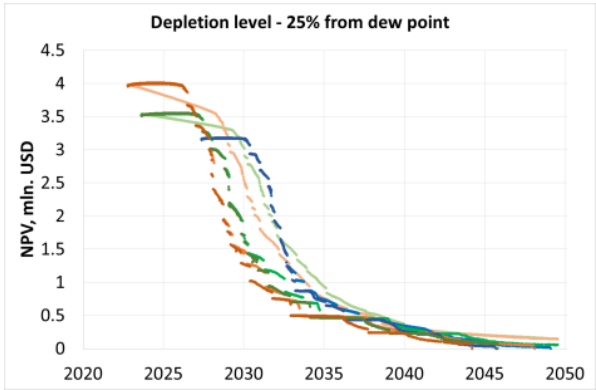

Fig. 4. Production profiles for gas (a), condensate (b), water (c) and NPV (d) for the injection case that started at $25 \%$ reservoir pressure decline from dew point.

(a)

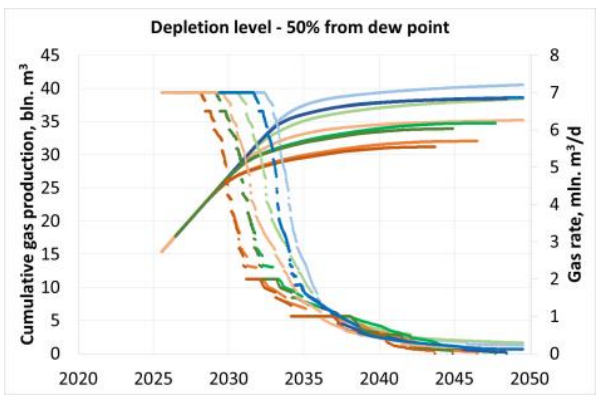

(c)

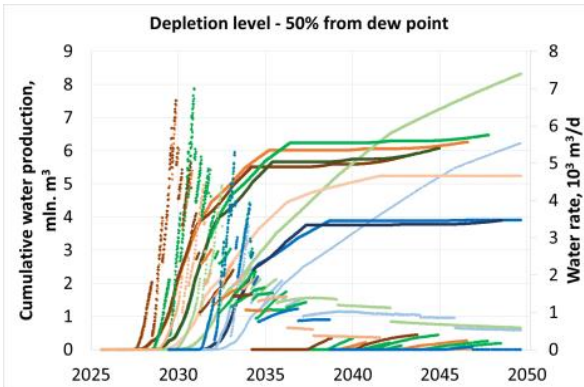

(b)

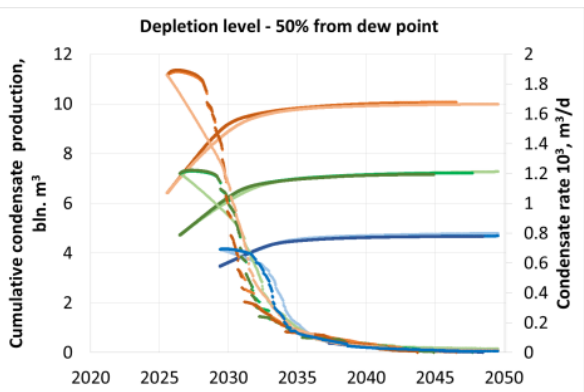

(d)

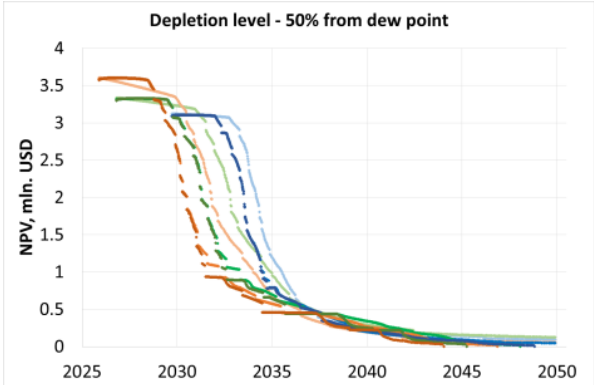

Fig. 5. Production profiles for gas (a), condensate (b), water (c) and NPV (d) for the injection case that started at $50 \%$ reservoir pressure decline from dew point. 
(a)

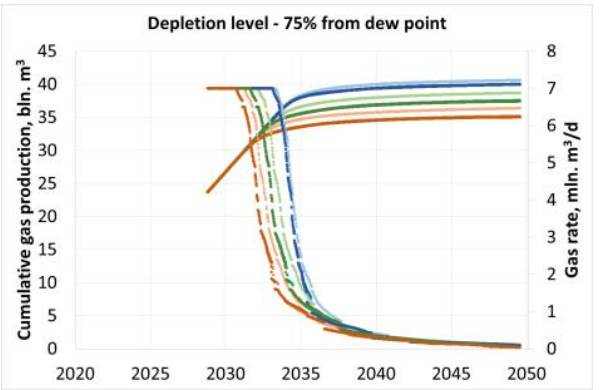

(c)

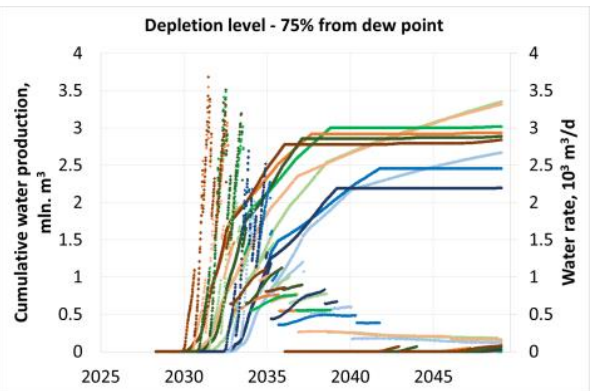

(b)

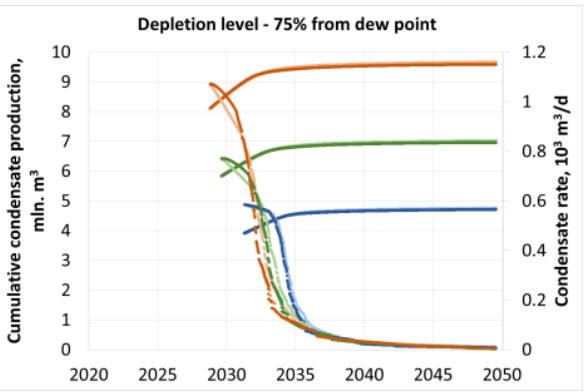

(d)

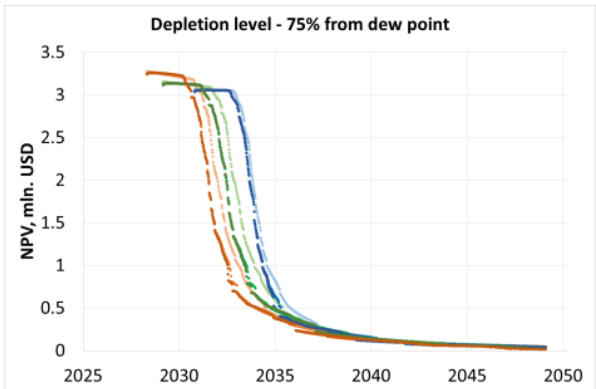

Fig. 6. Production profiles for gas (a), condensate (b), water (c) and NPV (d) for the injection case that started at $75 \%$ reservoir pressure decline from dew point.

(a)

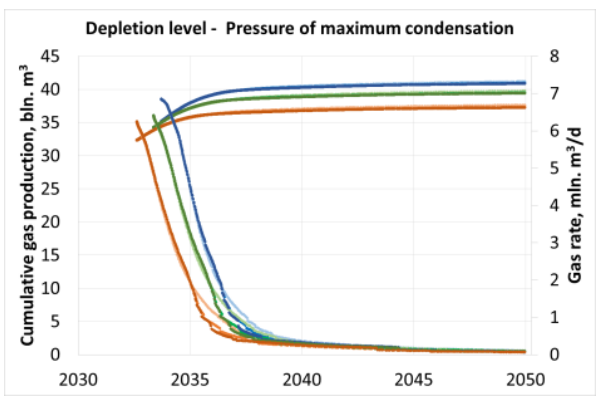

(c)

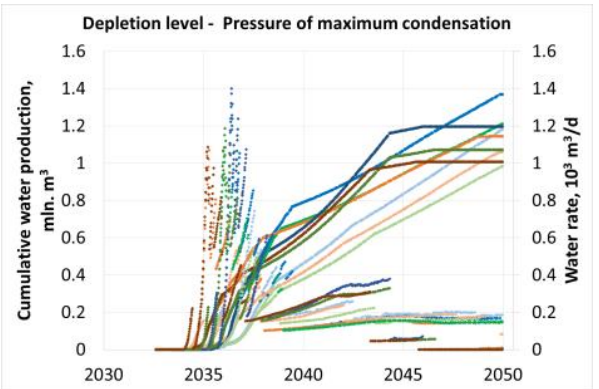

(b)

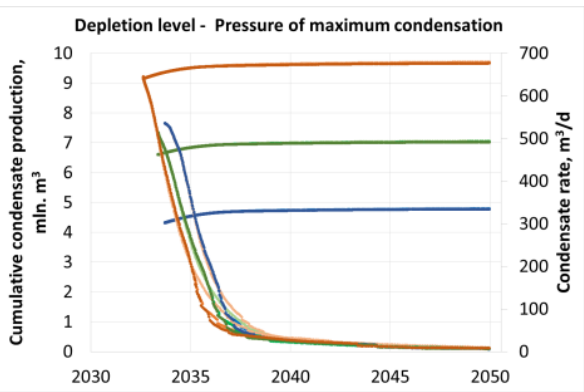

(d)

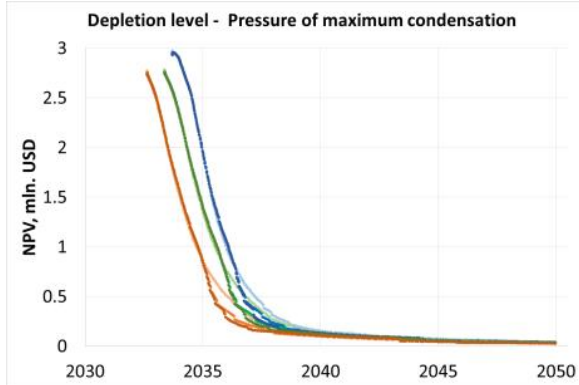

Fig. 7. Production profiles for gas (a), condensate (b), water (c) and NPV (d) for the injection case that started at the reservoir pressure equal to the pressure of maximum condensation. 
For reservoir systems with medium and high potential yield of liquid hydrocarbons $\mathrm{C}_{5+}$, the largest incremental recovery is obtained in the case when water injection starts with minimal depletion of reservoir energy (Fig. 8). While for a fluid system with a low potential yield $\left(100 \mathrm{~g} / \mathrm{m}^{3}\right)$ the maximum technological effect is obtained under the condition of maximum depletion. Also, for low condensate yield, partial maintenance of formation pressure is optimal, which does not slow down the rapid water breakthrough into production wells. In the case of medium and high $\mathrm{C}_{5+}$ yield in the formation gas, with a slight decrease in the formation pressure of 25 or $50 \%$ of the dew point pressure, the maximum increase in the condensate extraction coefficient is achieved at high injection rates with 100 or $150 \%$ injection to withdrawal. If flooding is introduced when the formation pressure has decreased by $75 \%$ relatively to the dew point pressure, incremental condensate recovery is practically absent.
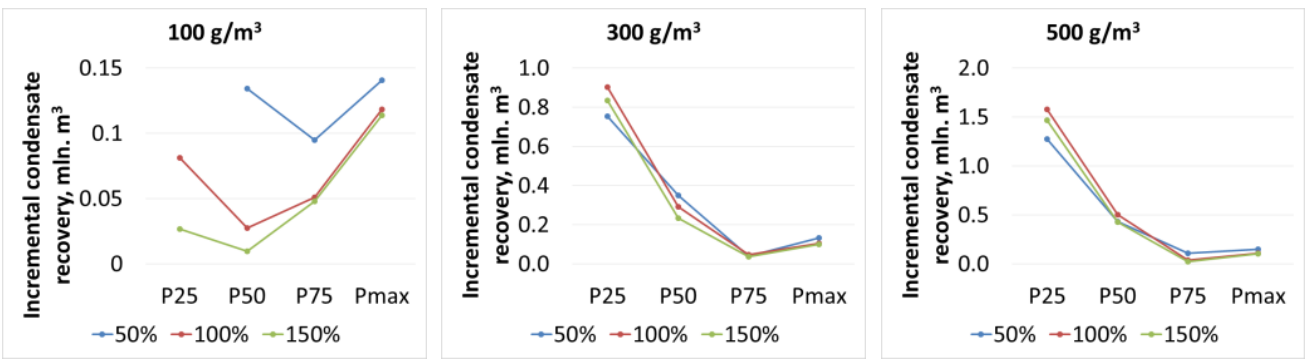

Fig. 8. Relation between incremental condensate recovery, level of reservoir depletion and voidage replacement ratio.

The use of an artificial inhomogeneous model of the reservoir as close as possible to the conditions of deep gas condensate fields DDD allowed us to evaluate the efficiency of possible use of flooding to increase hydrocarbon recovery at different stages of development and draw appropriate conclusions and provide practical recommendations.

\section{Conclusions}

The use of numerical 3D modeling of the field development processes, allows us to analyse many options and establish the optimal actions in order to achieve the maximum effect depending on the objectives.

Taking into account the multi-layered structure of DDD fields, the presence of oil reservoirs and frequently faced water drive in the gas reservoirs [22, 23], which leads to a gradual increase in the amount of produced water and the necessity of its injection or disposal, the efficiency of water flooding application to increase hydrocarbon recovery from gas condensate reservoir was investigated. The paper presents calculation results for the conditions of deeply buried gas condensate deposits of DDD with different potential yield: low $\left(100 \mathrm{~g} / \mathrm{m}^{3}\right)$, medium $\left(300 \mathrm{~g} / \mathrm{m}^{3}\right)$ and high $\left(500 \mathrm{~g} / \mathrm{m}^{3}\right)$ at different stages of the depletion drive, which were defined as the decrease of the average weighted formation pressure below the dew point pressure by $25,50,75 \%$ and at the pressure of maximum condensation. The comparison of the results was performed in relation to the base depletion case.

As a result, the positive effect of water injection on incremental condensate recovery, with a significant reduction in gas production. Therefore, we do not recommend the use of intra-contour flooding for gas deposits.

The increase in the final condensate recovery factor depends on the point of time of flooding introduction, the sooner the better. This is due to the possibility of maintaining 
reservoir pressure and displacement of already condensed liquid hydrocarbons. At the same time, partial voidage replacement is recommended in order to delay the time of water breakthrough, in our case it is injection to withdrawal at the level of $50 \%$. It is not recommended to introduce water injection when the formation pressure has decreased by $75 \%$ relatively to the dew point pressure, as incremental condensate recovery is almost absent compared to the depletion drive.

\section{References}

1. Meng, X., Yu, Y., Sheng, J., \& Watson, M. (2015). An experimental study on huff-n-puff gas injection to enhance condensate recovery in shale gas reservoirs. Unconventional Resources Technology Conference. https://doi.org/10.15530/URTEC-2015-2153322

2. Gurevych, G.R. (1985). Sposoby povysheniya kondensatootdachi plastov. Itogi Nauki i Tekhniki. Seriya: Razrabotka Neftyanykh i Gazovykh Mestorozhdeniy, 132-184.

3. Thomas, F., Holowach, N., Zhou, X., \& Bennion, D. (1994). Optimizing production from gas condensate reservoirs. Petroleum Society of Canada. Annual Technical Meeting. https://doi.org/10.2118/94-04

4. Burakov, Y.G., Ivanov, V.V., Ulyashev, E.V., Mikhailov, A.P., \& Roganov, R.V. (2008). Methods for reviving highly drowned gas wells of the Vuktylskoye Field (Russian). SPE Russian Oil and Gas Technical Conference and Exhibition. https://doi.org/10.2118/117419-ru

5. Lobanova, O.A., Indrupskiy, I.M., \& Yushchenko, T.S. (2016). Modeling non-equilibrium dynamics of condensate recovery for mature gas-condensate fields. SPE Russian Petroleum Technology Conference and Exhibition. https://doi.org/10.2118/181977-ms

6. Gurevich, G., Sokolov, V., \& Shmyglia, P. (1976). Razrabotka gazokondensatnykh mestorozhdeniy s podderzhaniem plastovogo davlenia. Moskva, Rossiya: Nedra, $183 \mathrm{~s}$.

7. Konnov, V.A., Fattakhov, R.B., \& Abramov, M.A. (2019). Application of positive displacement plunger-type pumps in reservoir pressure maintenance systems. Neftyanoe Khozyaystvo - Oil Industry, (1), 62-65. https://doi.org/10.24887/0028-2448-2019-1-62-65

8. Davidovskiy, A.O., Abramochkin, S.A., \& Lopatina, N.G. (2017). Multiphase gas-condensate metering tests with individual fluid properties model (Russian). SPE Russian Petroleum Technology Conference. https://doi.org/10.2118/187753-ru

9. Glumov, D.N., Reitblat, E.A., \& Buchinskiy, S.V. (2013). Performance evaluation of gas condensate wells treatment with $\operatorname{lng}$ rims and dry gas displacement (Russian). SPE Arctic and Extreme Environments Technical Conference and Exhibition. https://doi.org/10.2118/166888-ru

10. Samuel, S., \& Russell, J.G. (1964). Pressurizing oil fields. Patent No. 3150716 . United States.

11. Talday, I. (1989). Povyshenie kondensatootdachi chastichno istoschennoy zalezhi. Gazovaya Promyshlennost', (11), 42-43.

12. Burakov, Yu., Ulyashev, V., \& Guzhov, N. (1991). Analiz effektivnosti i mechanizma vodogazovogo vozdeystviya na vypavshyy v plaste kondensat. Gazovaya Promyshlennost', (7), 29-30.

13. Fishlock, T.P., \& Probert, C.J. (1996). Waterflooding of gas condensate reservoirs. SPE Reservoir Engineering, 11(04), 245-251. https://doi.org/2118/35370-pa

14. Bybee, K. (2000). Well productivity in gas/condensate reservoirs. Journal of Petroleum Technology, 52(04), 67-68. https://doi.org/10.2118/0400-0067-jpt

15. Thomas, F.B., Zhou, X., Bennion, D.B., \& Bennion, D.W. (1995). Towards optimizing gas condensate reservoirs. Annual Technical Meeting. https://doi.org/10.2118/95-09

16. Seah, Y.H., Gringarten, A.C., Giddins, M.A., \& Burton, K. (2014). Optimising recovery in gas condensate reservoirs. SPE Asia Pacific Oil \& Gas Conference and Exhibition. https://doi.org/10.2118/171519-ms

17. Ter-Sarkisov, R., Nikolaev, V., \& Kurbanov, A. (1990). Issledovanie vytesnenia vypavhego v plaste kondensata pri nalichii svyazannoy vody. Gazovaya Promyshlennost', (7), 49-50. 
18. Thomas, F.B., Holowach, N., Zhou, X., \& Bennion, D.B. (1994). Optimizing production from gas condensate reservoirs. Annual Technical Meeting. https://doi.org/10.2118/94-04

19. Burachok, O., Pershyn, D., Matkivskyi, S., Bikman, Ye., \& Kondrat, O. (2020). Osoblyvosti vidtvorennia rivniannia stanu hazokondensatnykh sumishei za umovy obmezhenoi vkhidnoi informatsii. Rozvidka ta Rozrobka Naftovykh $i$ Hazovykh Rodovyshch, 1(74), 82-88. https://doi.org/10.31471/1993-9973-2020-1(74)-82-88

20. Burachok, O.V., Pershyn, D., Matkivskyi, S., \& Kondrat, O. (2020). Doslidzhennia mezhi zastosuvannia PVT-modeli "chornoi nafty" dlia modeliuvannia hazokondensatnykh pokladiv. Mineralni Resursy Ukrainy, (2), 43-48. https://doi.org/10.31996/mru.2020.2.43-48

21. Burachok, O., \& Kondrat, O. (2019). Optimization of gas-condensate reservoir EOR technology under geological uncertainties. IOR 2019 - 20th European Symposium on Improved Oil Recovery. https://doi.org/10.3997/2214-4609.201900130

22. Kondrat, O., Lukin, O., \& Smolovyk, L. (2019). Analysis of possibilities to increase oil recovery with the use of nitrogen in the context of deep oil deposits of the Dnipro-Donetsk oil-and-gas Ukrainian province. Mining of Mineral Deposits, 13(4), 107-113. https://doi.org/10.33271/mining13.04.107

23. Kondrat, O. (2013). The enhancement of hydrocarbon recovery from depleted gas and gascondensate fields. Mining of Mineral Deposits, 143-148. https://doi.org/10.1201/b16354-24 